\title{
Ketentuan Pidana Denda Dalam KEJAHATAN KORUPSI DI TINGKAT EXTRAORDINARY CRIME
}

\author{
Wahyuningsih $\mid$ Desa Bangsri Sukodono \\ wahyu_ningsih@gmail.com $\mid$ Sidoarjo
}

\begin{abstract}
The provision of the criminal penalty of corruption at the extraordinary crime level has been stipulated in Law No. 20 Year 2001 Article 2 Paragraph (1) on corruption eradication. The criminal sanction has a better benefit than that of deprivation criminal penalty. It also has effectiveness in deterring corruption. The provision of criminal penalty in corruption in the level of extraordinary crime in term of Islamic criminal law has similarity in punishment for the guilty by paying the property as punishment for sinner. The difference is in the application of criminal penalty by using proportional principle that the sanction imposed should be in accordance with the severity of the offense that has been done. Islamic criminal law perspective uses the principle of restorative justice with the purpose of prevention, reconciliation, and forgiveness in the context of peace. Moreover, the penalty in Islamic criminal law does not set a lower or upper limit, it is left entirely to judge.
\end{abstract}

Keywords: Fine, corruption, extraordinary crime, Islamic criminal law

Abstrak: Ketentuan pidana denda dalam kejahatan korupsi di tingkat extraordinary crime diatur dalam UU No. 20 Tahun 2001 tentang Pemberantasan Tindak Pidana Korupsi dalam pasal 2 ayat (1). Pidana denda mempunyai manfaat lebih baik dari pada sanksi pidana perampasan dan memiliki efektivitas dalam membuat jera pelaku korupsi. Ketentuan pidana denda dalam kejahatan korupsi di tingkat extraordinary crime ditinjau hukum pidana Islam mempunyai kesamaan yaitu hukuman bagi orang yang berdosa dengan cara membayar harta sebagai sanksi atas dosanya. Perbedaannya terletak pada penerapan pidana denda dengan menggunakan prinsip proposional bahwa sanksi yang dikenakan harus sesuai dengan beratnya pelanggaran yang telah dilakukan. Sedangkan hukum pidana Islam menggunakan prinsip restorative justice dengan berpangkal tolak pada upaya pencegahan, rekonsiliasi dan pemaafan dalam rangka perdamaian. Kemudian hukum denda dalam pidana Islam tidak menetapkan batas terendah atau tertinggi, hal sepenuhnya diserahkan kepada hakim.

Kata Kunci: Denda, korupsi, extraordinary crime, fiqh jinâyah. 


\section{Pendahuluan}

UUD NRI 1945 menegaskan bahwa negara Indonesia berdasarkan atas hukum (rechtstaat), tidak berdasarkan atas kekuasaan belaka (machstaat). Ini berarti bahwa Republik Indonesia adalah negara hukum yang demokratis berdasarkan Pancasila dan UUD NRI 1945, menjunjung tinggi hak asasi manusia, dan menjamin semua warga negara bersamaan kedudukannya di dalam hukum dan pemerintahan itu dengan tidak ada kecualinya. ${ }^{1}$

Dewasa ini masalah hukum pidana banyak dibicarakan dan menjadi sorotan, baik dalam teori hukum pidana itu merupakan keseluruhan peraturan-peraturan hukum yang menunjukkan perbuatanperbuatan mana yang seharusnya dikenakan pidana dan hukuman maupun dalam praktek dan bahkan ada usaha untuk menyusun Kitab Undang-Undang Hukum Pidana Nasional. Usaha tersebut adalah bertujuan untuk mengatasi berbagai kelemahan dan kekurangan yang ada dalam Kitab Undang-undang Hukum Pidana yang berlaku sekarang, yang merupakan peninggalan zaman penjajah yang dalam kenyataannya masih dipakai pada masa orde baru di zaman kemerdekaan ini, yang banyak pengaturan di dalamnya sudah tidak sesuai lagi dengan jiwa dan semangat Pancasila dan Undang-undang Dasar 1945 maupun dengan situasi dan kondisi masyarakat saat ini.

Bagian yang tidak terpisahkan dari hukum pidana adalah masalah pemidanaan. Bukan merupakan hukum pidana apabila suatu peraturan hanya mengatur norma tanpa diikuti dengan suatu ancaman pidana. ${ }^{2} \mathrm{Di}$ dalam Kitab Undang-Undang Hukum Pidana Indonesia, jenis-jenis pidana yang diancamkan terhadap pelaku tindak pidana diatur dalam pasal 10 KUHP yaitu pidana mati, pidana penjara, pidana kurungan, pidana denda dan pidana tambahan yang terdiri dari: pencabutan hakhak tertentu, perampasan barang-barang tertentu dan pengumuman putusan hakim. ${ }^{3}$ Kemudian berdasarkan Undang-Undang Nomor 20 Tahun 1946, pidana pokok tersebut ditambah pidana tutupan.

Berbagai jenis pidana pokok yang diancamkan terhadap pelaku tindak pidana, yang paling tidak disukai adalah pidana perampasan

\footnotetext{
${ }^{1}$ Evi Hartati, Tindak Pidana Korupsi (Jakarta: Sinar Grafika, 2007), 1.

${ }^{2}$ Niniek Suparni, Eksistensi Pidana Denda dalam Sistem Pidana dan Pemidanaan (Jakarta: Sinar Grafika, 1996), 2.

${ }^{3}$ Moeljatno, KUHP(Jakarta: PT Bumi Aksara, 2008), 5 .
} 
kemerdekaan, yaitu pidana penjara atau pidana kurungan. Banyak kritikan tajam yang ditujukan terhadap jenis pidana ini, baik apabila dilihat dari sudut eksistensinya maupun bila dilihat dari akibat-akibat negatif lainnya yang menyertai atau berhubungan dengan dirampasnya kemerdekaan seseorang. Meskipun demikian, dari jenis-jenis pidana tersebut di atas, pidana yang merupakan kehilangan kemerdekaanlah yang paling banyak diancamkan, baik secara tunggal maupun secara alternatif, serta dapat untuk waktu tertentu ataupun seumur hidup. Pada masa sekarang ini maksud dijatuhkannya pidana perampasan kemerdekaan adalah agar dengan pidana itu dapat dilakukan pembinaan sedemikian rupa sehingga setelah selesai menjalani pidananya, maka diharapkan terpidana akan menjadi manusia yang lebih baik dari sebelumnya.

Penjatuhan pidana dan pemidanaan dapat dikatakan cermin peradilan kita. Apabila proses peradilan yang misalnya berakhir dengan penjatuhan pidana itu berjalan sesuai asas peradilan, niscaya peradilan kita dinilai baik. ${ }^{4}$ Apabila sebaliknya, tentu saja dinilai sebaliknya pula. Bahkan dapat dicap sebagai ada kemerosotan kewibawaan hukum.

Hukum menetapkan apa yang harus dilakukan dan atau apa yang boleh dilakukan serta yang dilarang. Sasaran hukum yang hendak dituju bukan saja orang yang nyata-nyata berbuat melawan hukum, melainkan juga perbuatan hukum yang mungkin akan terjadi, dan kepada alat perlengkapan negara untuk bertindak menurut hukum. Sistem bekerjanya hukum yang merupakan satu bentuk penegakan hukum.

Proses pembangunan dapat menimbulkan kemajuan dalam kehidupan masyarakat, selain itu dapat juga mengakibatkan perubahan kondisi sosial masyarakat yang memiliki dampak sosial negatif, terutama menyangkut masalah peningkatan tindak pidana yang meresahkan masyarakat. Salah satu tindak pidana yang dapat dikatakan cukup fenomenal adalah masalah Korupsi. Tindak pidana Korupsi dikategorikan extraordinary crime (kejahatan luar biasa) karena dampak yang ditimbulkan memang luar biasa. Sebab, korupsi yang selama ini terjadi secara sistemik dan meluas, tidak hanya merugikan negara, mengganggu stabilitas dan keamanan masyarakat, serta melemahkan

\footnotetext{
${ }^{4}$ Bambang Waluyo, Pidana dan Pemidanaan (Jakarta: Sinar Grafika,2000), 34.

${ }^{5}$ Aziz Syamsuddin, Tindak Pidana Khusus (Jakarta : Sinar Grafika, 2011), 175.
} 
nilai-nilai demokrasi, etika keadilan, dan kepastian hukum, sehingga dapat membahayakan kelangsungan pembangunan, tetapi juga telah melanggar terhadap hak-hak sosial dan ekonomi masyarakat luas, yang merupakan perilaku jahat yang cenderung sulit untuk ditanggulangi dan korupsi digolongkan sebagai kejahatan yang pemberantasanya juga harus dilakukan secara luar biasa.

Undang-undang Pemberantasan Tindak Pidana Korupsi yaitu UU No.31 Tahun 1999 yang kemudian diperbaharui dengan UU No.20 Tahun 2001 telah mengatur berbagai strategi pemberantasan korupsi. Strategi tersebut lebih diperkuat lagi pada Desember 2003 berdasarkan UU NO.30 Tahun 2002 telah dibentuk lembaga negara dengan nama Komisi Pemberantasan Korupsi. ${ }^{6}$ KPK kerap dijuluki oleh kalangan hukum sebagai lembaga "superbody" karena wewenang yang dimilikinya luar biasa besar untuk menyelidiki, menyidik, dan menuntut setiap orang, pegawai negeri, penyelenggara negara, dan bahkan korporasi yang diduga telah melakukan Korupsi, sehingga menimbulkan kerugian pada keuangan/perekonomian negara. ${ }^{7}$

KPK adalah suatu lembaga yang bersifat independen dan bebas dari pengaruh kekuasaan manapun. ${ }^{8}$ Tujuan pembentukannya, yaitu untuk meningkatkan daya guna dan hasil guna terhadap upaya pemberantasan tindak pidana korupsi, dengan asas pada kepastian hukum, keterbukaan, akuntabilitas, kepentingan umum, dan proposional. Lembaga KPK ini hadir untuk membantu lembaga kepolisian dan kejaksaan yang selama ini dianggap lamban dan memiliki integritas yang rendah terkait pemberantasan korupsi, karena beberapa aparatnya pun tersangkut dalam beberapa kasus korupsi. Selain itu untuk lebih memperkuat lagi, dihadirkan pula pengadilan khusus untuk mengadili para pelaku korupsi yaitu Pengadilan Tindak Pidana Korupsi (Pengadilan Tipikor) dengan UU No.46 tahun 2009 tentang Pengadilan Tindak Pidana Korupsi. ${ }^{9}$

Telah dipaparkan diatas bahwa strategi pemberantasan korupsi telah dilakukan sedemikian rupa yang salah satunya dengan mengancam dengan berbagai macam pidana kepada para pelaku korupsi dengan

\footnotetext{
${ }^{6}$ Ermansjah Djaja, Memberantas Korupsi Bersama KPK (Jakarta: Sinar Grafika, 2008), 10.

${ }^{7}$ Aziz Syamsuddin, Tindak Pidana Khusus, 193.

${ }^{8}$ Ermansjah Djaja, Memberantas Korupsi Bersama KPK, 19.

${ }^{9}$ Lihat UU No. 46 Tahun 2009 tentang Pengadilan Tindak Pidana Korupsi.
} 
pidana yang cukup berat jika dibandingkan dengan pidana-pidana lain dalam peraturan perundang-undangan lainnya. Meskipun telah diancam dengan pidana yang relatif berat, namun dalam kenyataannya perilaku korup dan jumlah perkara korupsi justru tidak dapat ditekan bahkan cenderung lebih bertambah.

Tentu terdapat suatu persoalan yang menyebabkan hal ini terjadi. Jika ditengok dan diselidiki, ternyata penyebabnya itu tidak perlu jauhjauh sampai pada mental masyarakat dan mental aparat, permasalahan itu terletak pada regulasi pemberantasan tindak pidana korupsi itu sendiri. Persoalan regulasi yang dimaksudkan adalah pada ancaman pidananya. Menurut UU No. 31 Tahun 1999 jo. UU No. Tahun 2001, bentuk sanksi pidana yang dapat dikenakan kepada pelaku tindak pidana korupsi adalah pidana penjara dan pidana denda. ${ }^{10}$

Pidana denda dalam tindak pidana korupsi dirasa terlalu kecil ancamannya mulai dari pidana denda paling sedikit Rp 200.000.000 (dua ratus juta rupiah) sampai ke pidana denda maksimal Rp. 1.000.000.000 (satu miliar rupiah). ${ }^{11}$ Pidana denda juga hanya sebagai hukuman alternatif yang memungkinkan jika pelaku korupsi tidak dapat membayar denda tersebut, hanyalah dikenakan pidana kurungan yang maksimumnya hanya 6 (enam) atau 8 (delapan) bulan. Kemudian, Pidana denda merupakan satu-satunya pidana yang dapat dan dibayar atau ditanggung oleh orang lain selain terpidana. Tidakkah dengan demikian para koruptor dapat dengan leluasa berbuat tindak pidana korupsi sebab ia merasa bahwa pertanggungan jawab akan dipikul oleh orang lain dan hasil kurupsi tetap dapat dinikmati dengan tidak perlu khawatir harta benda atau kekayaannya akan dirampas atau disita. Walaupun hakim dapat pula menjatuhkan pidana tambahan, namun yang dapat dirampas hanyalah barang-barang yang diduga diperoleh dari hasil kejahatan atau sengaja dipergunakan untuk melakukan kejahatan.

Islam menetapkan aturan hukum syari'at, yang mana tujuan utama syari'at Islam ialah untuk menjaga dan melindungi lima sasaran pokok atau populer dengan istilah al-maqâssid al-shar'iyah, yaitu perlindungan terhadap agama (hifz al-dîn), perlindungan terhadap jiwa (hifz al-nafs), perlindungan terhadap akal (hifz al-'aq), perlindungan

\footnotetext{
${ }^{10}$ Evi Hartati, Tindak Pidana Korupsi, 12.

${ }^{11}$ Aziz Syamsuddin, Tindak Pidana Khusus, 154.
} 
terhadap keturunan (hifz al-nas), dan perlindungan terhadap harta (hifz al-m I).

Kelima al-maqâssid al-shar'iyah tersebut, jika terlaksana dengan baik, maka akan tercapailah apa yang disebut dengan kebaikan di dunia dan kebaikan di akhirat (fi al-dunyâ ḥasanah, wa fi al-âkhirah ḥasanah). Sebaliknya, segala tindakan yang bisa mengancam keselamatan salah satu dari kelima hal pokok tersebut, maka Islam menganggapnya sebagai tindak kejahatan (jarîmah) yang terlarang, oleh karenanya pelakunya dikenakan hukuman atau sanksi baik yang bersifat duniawi dan/atau ukhrawi. Hukuman ukhrawi berupa siksa neraka yang disesuaikan dengan kejahatannya. Hukuman duniawi adalah hukuman yang diputuskan dan dilaksanakan hukumannya di dunia. Dalam hal ini ada dua kemungkinan, jika secara jelas (sarih) ditegaskan oleh nash, maka disebut qișâs, diyat dan had. Jika tidak secara tegas (ghair șarih) disebutkan dalam nash maka disebut ta'zîr, yang mana sanksi hukumannya diserahkan kepada pertimbangan hakim. ${ }^{12}$

Tindak pidana korupsi jelas merupakan perlawanan terhadap tujuan kelima; hifz̧ al-mâl. Apabila dalam kepustakaan hukum Islam, contoh populer perbuatan melawan tujuan hifz̧ al-mâl ini adalah kejahatan mencuri (al-sarîqah) milik perorangan, namun korupsi (alikhtilâs) merupakan salah satu tindak kejahatan harta, yaitu memakan harta manusia dengan cara yang batil.

Firman Allah dalam surat al-Baqarah ayat 188:

"Dan janganlah sebahagian kamu memakan harta sebahagian yang lain di antara kamu dengan jalan yang bathil dan (janganlah) kamu membawa (urusan) harta itu kepada hakim, supaya kamu dapat memakan sebahagian daripada harta benda orang lain itu dengan (jalan berbuat) dosa, Padahal kamu mengetahui"'13

Lebih spesifik lagi, pada surat Ali Imran ayat 161 korupsi termasuk dalam kategori ghulûl (pengkhianatan wewenang), ${ }^{14}$ dimana pelakunya menyalahgunaan harta negara, perusahaan, atau masyarakat, demi kepentingan pribadinya. Jadi korupsi sebagai kejahatan mencuri

\footnotetext{
${ }^{12}$ Ahmad Wardi Muslich, Hukum Pidana Islam (Jakarta: Sinar Grafika, 2005), 258.

13 Departemen Agama RI, A-Qur'an dan Terjemahannya (Surabaya: Pustaka Agung Harapan, 2006), 36.

${ }^{14}$ Lihat surat Ali Imran ayat 161
} 
harta milik bangsa dan negara lebih layak lagi untuk dicatat sebagai pelanggaran yang sangat serius terhadap prinsip hifź al-mâl.

Meskipun nash tidak secara langsung menjelaskan had atau dendanya, bukan berarti pelaku korupsi bebas dari hukuman. Had tersebut berpindah menjadi ta'zîr yang kebijakannya diserahkan kepada hakim (ulil amrì). ${ }^{15}$ Tentunya kebijakan tersebut tidak serta merta berdasarkan pada kepentingan hawa nafsunya, akan tetapi harus memperhatikan ketentuan yang berlaku dalam hukum Islam.

Hukuman ta'zîr ini jenisnya beragam, namun secara garis besar dapat dikelompokkan kepada empat kelompok yaitu: Pertama, hukuman ta'zîr yang mengenai badan, seperti hukuman mati dan dera. Kedua, hukuman yang berkaitan dengan kemerdekaan seseorang, seperti hukuman penjara dan pengasingan. Ketiga, hukuman ta'zîr yang berkaitan dengan harta, seperti denda, penyitaan/perampasan harta, dan penghancuran barang. Ketiga, hukuman-hukuman lain yang ditentukan oleh ulil amri demi kemaslahatan umum. ${ }^{16}$

Seperti uraian yang telah dikemukakan di atas, khususnya pada bagian ketiga dari jenis ta'zîr dengan harta, dapat diketahui bahwa wujud dari pemilikan harta itu adalah denda atau dalam bahasa Arab disebut ahar mah. ${ }^{17}$

Berdasarkan berbagai konsepsi diatas, maka penulis tertarik membahas tentang pertanggungjawaban kejahatan korupsi, khususnya tentang penerapan ketentuan pidana denda, agar dapat memberikan konsepsi hukum yang jelas terkait perbuatan korupsi dan memudahkan untuk memberikan sangksi hukum yang sesuai dengan perbuatannya.

\section{Pengertian Kejahatan Korupsi}

Korupsi adalah salah satu bentuk kejahatan yang berdampak amat besar di berbagai aspek kehidupan. Berbagai cara korupsi yang telah dilakukan oleh beberapa orang, telah menimbulkan banyak kerugian baik bagi negara maupun masyarakat. Para pelaku korupsi dengan tanpa malu melakukannya, dan bahkan korupsi kerapkali dilakukan secara

\footnotetext{
${ }^{15}$ Ahmad Wardi Muslich, Hukum Pidana Islam, 258.

16 Ibid., 258.

${ }^{17}$ Ibid., 267.
} 
berjama'ah. Hal ini menunjukkan begitu rusaknya moral manusia, yang tanpa malu dan bahkan terang-terangan melakukan kejahatan.

Korupsi merupakan suatu bentuk perbuatan melawan hukum yang merugikan keuangan atau perekonomian negara. Adapun yang dimaksud dengan tindakan melawan hukum adalah suatu perbuatan atau tidak berbuat sesuatu yang mengakibatkan timbulnya kerugian bagi orang lain. Dimana perbuatan atau tidak berbuat tersebut merupakan perbuatan sengaja atau merupakan suatu kecelakaan. ${ }^{18}$

Untuk pertama kalinya secara normatif Pengertian korupsi mengacu pada ketentuan pasal 1 ayat (1) a dan b UU No. 3 Tahun 1971, menyebutkan yang termasuk dalam tindak pidana korupsi ialah:

a. Barang siapa dengan melawan hukum melakukan perbuatan memperkaya diri sendiri atau orang lain, atau suatu badan, yang secara langsung atau tidak langsung merugikan keuangan negara dan atau perekonomian negara, atau diketahui atau patut disangka olehnya bahwa perbuatan tersebut merugikan negara atau perekonomian negara;

b. Barang siapa dengan tujuan menguntungkan diri sendiri atau orang lain atau suatu badan, menyalahgunakan kewenangan, kesempatan atau sarana yang ada padanya karena jabatan atau kedudukan, yang secara langsung atau tidak langsung dapat merugikan keuangan negara atau perekonomian negara; ${ }^{19}$

Selanjutnya Undang-Undang No. 3 Tahun 1971 tentang Pemberantasan Tindak Pidana Korupsi tersebut disempurnakan dengan UU No. 31 Tahun 1999 dan UU Perubahanya yakni UU No. 20 Tahun $2001^{20}$. Sementara itu, apa yang tercakup dalam perbuatan tindak pidan korupsi menurut adalah melakukan perbuatan seperti dimaksud dalam pasal 2, pasal 3, pasal 5, pasal 6, pasal 7, pasal 8, pasal 9, pasal 10, pasal 11, pasal 12, pasal 12B, pasal 13 dan pasal 14 .

Rumusan delik korupsi sebagaimana yang dimaksud pada ketentuan pasal di atas, dapat diambil unsur-unsur delik sebagai berikut:

1) Perbuatan melawan hukum

2) Menyalahgunakan wewenang

\footnotetext{
${ }^{18}$ Munir Fu'ady, Perbuatan Melawan Hukum (Bandung: PT. Citra Aditya Bhakti, 2005), 4.

${ }^{19}$ Lihat pasal 1 ayat (1) a dan b UU No. 3 Tahun 1971 tentang Pemberantasan Tindak Pidana Korupsi

${ }^{20} \mathrm{lbid}, 5$.
} 
3) Memperkaya diri sendiri atau orang lain atau korporasi

4) Berpotensi merugikan keuangan negara

Ditinjau dari segi istilah, kata korupsi berasal dari bahasa Latin curruptio. selanjutnya disebutkan bahwa curruptio itu berasal pula dari kata asal currupere, suatu kata Latin yang lebih tua. Dari bahasa Latin itulah turun ke bahasa Eropa seperti curruption dan currupt (Inggris), curruption (Perancis), dan curruptie (kurruptie) (Belanda). ${ }^{21}$ Selanjutnya istilah korupsi diserap dan diterima dalam perbendaharaan kata di Indonesia, sebagaimana menurut pendapatnya Poerwadarminta yang dituangkan dalam Kamus Umum Bahasa Indonesia. ${ }^{22}$ Korupsi adalah perbuatan yang buruk seperti penggelapan uang, penerimaan uang sogok dan sebagainya.

Secara harfiah, korupsi adalah kebusukan, kebejatan, ketidak jujuran, dapat disuap, penyimpangan dari kesucian. Sedangkan menurut pasal 1 ayat (1) UU No. 31 Tahun 1999 jo UU No. 20 Tahun 2001 tentang Tindak Pidana Korupsi, menyatakan bahwa korupsi adalah kumpulan orang dan atau kekayaan yang terorganisasi baik merupakan badan hukum maupun bukan badan hukum.

Makna korupsi berkembang dari waktu ke waktu sebagai pencerminan kehidupan masyarakat dari sisi negatif. Semula istilah korupsi merupakan istilah yang banyak dipakai dalam ilmu politik, kemudian menjadi sorotan berbagai disiplin ilmu.

Ada beberapa definisi lain yang dimuat dalam berbagai literatur, yang menjelaskan tentang pengertian korupsi menurut para sarjana, antara lain:

a) Sayed Hussein Alatas dalam bukunya Corruption: Its Nature, Causes and Consequences, menulis:

Korupsi adalah subordinasi kepentingan umum di bawah kepentingan tujuan-tujuan pribadi yang mencakup pelanggaran norma-norma, tugas, dan kesejahteraan umum, dibarengi dengan kerahasiaan, penghianatan, penipuan, dan kemasabodohan yang luar biasa akan akibat-akibat yang diderita oleh masyarakat, singkatnya, korupsi adalah penyalahgunaan amanah untuk kepentingan pribadi. ${ }^{23}$

${ }^{21}$ Andi Hamzah, Pemberantasan Korupsi Melalui Hukum Pidana Nasional dan Internasional (Jakarta: Rajagrafindo Persada, 2007), 4.

${ }^{22}$ W.J.S Poerwadarminta, Kamus Umum Bahasa Indonesia (Jakarta: Balai Pustaka, 1976), 524.

${ }^{23}$ Aziz Syamsuddin, Tindak Pidana Khusus, 137. 
b) Baharuddin Lopa mengutip pendapat dari Dvid M. Chalmers, menguraikan arti istilah korupsi dalam berbagai bidang, yakni yang menyangkut masalah penyuapan, yang berhubungan dengan manipulasi di bidang ekonomi, dan yang menyangkut bidang kepentingan umum. ${ }^{24}$

c) Dani Krisnawati dkk, mengutip ungkapan yang perna dikemukakan oleh Lord Acton sebagai berikut: "Power tends to corrupt, and absoute power corrupts absolutely", kekuasaan cenderung untuk korupsi dan kekuasaan yang absolut cenderung korupsi absolute. ${ }^{25}$

\section{Pidana Denda}

Pidana Denda adalah salah satu jenis pidana yang telah lama dikenal dan diterima dalam sistem hukum masyarakat bangsa-bangsa didunia. Walaupun tentu saja pengaturan dan cara penerapan pidana denda tersebut, bervariasi sesuai dengan kondisi dan perkembangan masyarakat.

Apabila dibandingkan dengan sistem pemidanaan di negeri Belanda, maka dapat dikatakan bahwa pola pemidanaan di Indonesia hanya mengenal pidana denda yang dikenakan oleh pengadilan. Sedangkan Belanda mengenal sanksi-sanksi ekstra pengadilan yang dapat melakukan transaksi denda yang harus dibayar agar suatu kasus tidak diteruskan ke pengadilan, yaitu: sanksi-sanksi ekstra yuridis berupa transaksi polisi, transaksi dengan kantor kejaksaan, pembebasan bersyarat, apabila telah dilakukan penuntutan. ${ }^{26}$

Untuk mengetahui kedudukan dan pola pidana denda di Indonesia. Maka hal yang pertama adalah melihat kembali dari ketentuan pasal 10 KUHP, yang menyatakan bahwa:

Pidana pokok terdiri dari:

a. Pidana mati

b. Pidana penjara

c. Pidana Kurungan

d. Pidana denda

e. Pidana tutupan

\footnotetext{
${ }^{24}$ Evi Hartati, Tindak Pidana Korupsi Edisi Kedua, 10.

${ }^{25}$ Ermannsjah Djaja, Meredesain Pengadilan Tindak Pidana Korupsi Implikasai Putusan Mahkamah Konstitusi Nomor 012-016-019/PPUIV/2006 (Jakarta: Sinar Grafika, 2010), 17.

${ }^{26}$ Soedjono D, Sistem Peradilan Pidana Peraturan Umum dan Delik-Delik Khusus (Jakarta: Rajawali Pers, 1989), 76.
} 
Pidana Tambahan, terdiri atas

a. Pencabutan hak-hak tertentu

b. Perampasan barang-barang tertentu

c. Pengumuman keputusan hakim

Berdasarkan urutan pada pidana pokok tersebut, pidana denda ditempatkan dalam kelompok pidana pokok sebagai urutan terakhir terkesan bahwa pidana denda adalah pidana pokok paling ringan. Walaupun tidak ada ketentuan yang dengan tegas menyatakan demikian. Berbeda halnya dengan Rancangan KUHP pada pasal 58 ayat (2) yang tegas-tegas menyatakan bahwa urutan pidana pokok diatas menentukan berat ringannya pidana. ${ }^{27}$

Sistem KUHP tidak mengenal batas maksimum umum pidana denda, melainkan hanya batas maksimum khusus dalam pasal-pasalnya. Sebaliknya dalam KUHP ditentukan batas maksimum umum pidana denda. Selengkapnya pasal 30 KUHP menyatakan:

1) Banyaknya denda sekurang-kurangnya 25 sen $(250,-)$

2) Jika dijatuhkan hukuman denda dan denda tidak dibayar, maka diganti dengan kurungan.

3) Lamanya hukuman kurungan pengganti itu sekurang-kurangnya satu hari dan selama-lamanya enam bulan.

4) Lamanya kurungan ini ditetapkan begitu rupa, bahwa harga setengah rupiah atau kurang diganti dengan satu hari, bagi denda yang lebih besar daripada itu, maka bagi tiap-tiap setengah rupiah diganti tidak lebih daripada satu hari, dan bagi sisanya yang tidak cukup setengah rupiah, lamanya pun satu hari.

5) Jika ada pemberatan denda karena perbarengan atau pengulangan atau karena ketentuan pasal 52 dan 52a, maka kurungan pengganti paling lama dapat menjadi delapan bulan.

Hal di atas merupakan aturan umum pola pemidanaan yang terdapat dalam KUHP. Dalam Undang-undang Tindak Pidana Korupsi, pidana penjara diformulasikan dengan pola minimum-maksimum khusus. Demikian pula dengan pidana denda, dimana formulasinya menerapkan pola minimum-maksimum khusus. ${ }^{28}$

\footnotetext{
${ }^{27}$ M. Hamdan, Politik Hukum Pidana (Jakarta: PT Raja Grafindo Persada, 1997), 144.

${ }^{28}$ Asmawi, Teori Maslahat dan Relevansinya Dengan Perundang-undangan Pidana Khusus di Indonesia (Jakarta: Badan LITBANG dan DIKLAT), 176.
} 
Perlu diketahui pula bahwa terdapat dalam Undang-undang Tindak Pidana Korupsi ketentuan ancaman pidana penjara dan denda hanya dengan menyebut kadar maksimum saja tanpa kadar minimumnya, yakni pasal 13 tentang suap-menyuap yang memuat ancaman pidana penjara maksimum 3 (tiga) tahun dan/atau pidana denda maksimum Rp. 150 juta, di mana kedua macam pidana ini dapat dijatuhkan secara kumulatif atau secara alternatif, sesuatu yang diimplikasikan dari penggunaan kata dan/atau dalam redaksi pasal tersebut.

Menurut UU No. 31 Tahun 1999 jo. UU No. 20 Tahun 2001 tentang Pemberantasan Tindaka Pidana Korupsi, ancaman pidana denda ditetapkan dengan dua format, yaitu format kumulatif, artinya hakim hanya boleh memilih satu jenis pidana saja dan format kombinasi kumulatif-alternatif, di mana hakim boleh memilih lebih dari satu jenis pidana. ${ }^{29}$ Pidana denda juga dapat dikatakan sebagai pidana gabungan atau sebagai pengganti dari kurungan yang tidak terbayar atau penggunaan pidana denda tunggal terhadap korporasi maupun sanksi denda yang dikumulasikan dengan tindakan, khususnya yang terdapat dalam putusan peradilan tindak pidana korupsi. Fenomena ini merupakan suatu permulaan dari kedudukan dan reposisi sanksi denda sebagai sanksi yang penggunaannya mulai digemari oleh legistator. ${ }^{30}$

Namun demikian, legistator tidak pernah memperhitungkan bagaimana proses eksekusi terhadap pidana denda yang tidak terbayar, sehingga mengganggu efektifitas penerapan pidana denda itu sendiri. Oleh karenanya bila denda tidak dibayar, maka mekanisme KUHP yang akan berlaku yakni dengan kurungan yang maksimum hanya delapan bulan. Dengan adanya ketentuan tersebut biasanya pelaku delik tindak pidana korupsi akan selalu memilih pidana kurungan daripada nestapa membayar denda yang tinggi. ${ }^{31}$

Penentuan pidana di luar KUHP juga menimbulkan permasalahan mengenai ketentuan batas maksimum pidana penjara dan denda, karena tidak banyak ditemukan standar penentuan kreteria atau pola pidana dalam suatu undang-undang di luar KUHP.

\footnotetext{
29 Ibid., 177.

30 Saiful Bakhri, "Kebijakan Legislatif tentang Pidana Denda dan Penerapannya dalam Upaya Penanggulanagan Tindak Korupsi", www.law.Ull.co.id ${ }^{31}$ Ibid.
} 
Maka ada upaya pidana denda dirumuskan dalam konsep Rancangan KUHP berdasarkan sistem kategori adalah sebagai berikut: ${ }^{32}$

a) Kategori I, seratus lima puluh ribu rupiah

b) Kategori II, tujuh ratus lima puluh ribu ribu rupiah

c) Kategori III, tiga juta rupiah

d) Kategori IV, tujuh juta lima ratus ribu rupiah

e) Kategori V, tiga puluh juta rupiah

f) Kategori VI, tiga ratus juta rupiah

Tujuan utama penggunaan kategori denda adalah:

(1) Agar diperoleh pola yang jelas tentang maksimum denda yang dicantumkan untuk berbagai tindak pidana (ada enam kategori)

(2) Agar mudah melakukan perubahan apabila terjadi perubahan dalam keadaan ekonomi dan moneter di negara kita. ${ }^{33}$

Perkembangan untuk memperluas penggunaan pidana denda dengan meningkatkan efektifitas pidana denda. Diperlukan suatu kebijakan yang menyeluruh baik dibidang legislatif, yudikatif maupun eksekutif. Menurut Muladi dan Barda Nawawi Arief, dalam pelaksanaan pidana denda perlu dipertimbangkan antara lain mengenai:

Sistem penetapan jumlah atau besarnya pidana denda

(a) Batas waktu pelaksanaan pembayaran denda.

(b) Tindakan-tindakan paksaan yang diharapkan dapat menjamin terlaksananya pembayaran denda dalam hal terpidana tidak dapat membayar dalam batas waktu yang telah ditetapkan.

(c) Pedoman atau kreteria untuk menjatuhkan pidana denda. ${ }^{34}$

Pidana denda obyeknya adalah harta benda yang berbentuk uang semata dan tidak boleh berbentuk natura atau barang, dapat dilihat dalam ketentuan KUHP yang mengatur hal ini. Konskuensinya, perkembangan ekonomi dan lalu lintas uang akan sangat pengaruh pada efektivitas pidana denda ini. Sebab itu jumlah yang telah ditetapkan dalam undang-undang akan bersifat relatif, misalnya karena inflasi. Oleh karena itu, perlu suatu perumusan yang tidak kaku dalam undangundang walaupun tentu saja tetap harus ada batasannya. Dalam hal ini diperlukan suatu jaminan terhadap kebebasan hakim yang lebih besar

\footnotetext{
${ }^{32}$ Bambang Waluyo, Pidana dan Pemidanaan, 20.

33 Ibid.

${ }^{34}$ Muladi dan Barda Nawawi A, Teori-teori dan Kebijakan Pidana (Bandung: Alumni, 1992), 181.
} 
untuk menentukan jumlah denda yang akan dijatuhkan. Hanya saja apabila denda tersebut tidak dibayar oleh terpidana baik karena ketidak mampuan atau pun ketidak mauannya, maka pidana denda itu dapat dikonversi ke dalam bentuk pidana kurungan yang disebut dengan hukuman kurungan subsider atau pengganti, bukan pidana kurungan prinsipal. ${ }^{35}$

Sebagaimana dipahami, undang-undang diluar KUHP seperti Undang-undang Tindak Pidana Korupsi, pada dasarnya hanya melengkapi perbuatan atau tindak pidana yang belum secara lengkap diatur di dalam KUHP yang merupakan induk aturan umum (general rules) di bidang hukum pidana substantif, yang diwadahi dalam Buku I KUHP. Sedangkan aturan pemidanaan yang bersifat khusus (special rules) diakomodasi dalam, baik Buku II dan Buku III KUHP maupun perundang-undangan pidana khusus di luar KUHP, yang adakalanya aturan khusus itu menyimpang dari ketentuan aturan umum. ${ }^{36}$ Peluang ini memang diberikan oleh KUHP itu sendiri dan hal ini merupakan pembuka jalan bagi pembentuk Undang-undang Tindak Pidana Korupsi untuk menyimpangi atau mengecualikan dari hal-hal yang secara umum diatur di dalam buku I KUHP, termasuk pengaturan mengenai pidana denda.

Sehubungan dengan masalah kejahatan korupsi, hukum pidana anti-korupsi memiliki pola pemidanaan yang khusus (special rules). Meskipun punya kesamaan dengan yang ada dalam hukum pidana umum, namun tetap mempunyai kekhususan. Pertama, pidana pokok yang dapat dijatuhkan secara bersamaan dapat dibedakan menjadi dua macam cara, yaitu cara imperatif-kumulatif di mana pidana pokok berupa pidana penjara dan denda kedua-duanya harus dijatuhkan secara simultan, kemudian dengan cara imperatif-fakultatif di mana pidana pokok yang harus dijatuhkan berupa pidana penjara (segi imperatif), bahkan juga dapat dikumulasikan dengan pidana denda (segi fakultatif). Kedua, terdapat ancaman minimum khusus dan maksimum khusus, baik menyangkut pidana penjara maupun pidana denda. Ketiga, batas maksimum khusus pidana penjara yang diancamkan (20 tahun) jauh melebihi batas maksimum umum yang ada dalam KUHP, yakni 15

\footnotetext{
${ }^{35}$ Suhariono AR, Pembaharuan Pidana Denda di Indonesia, 39.

${ }^{36}$ Aziz Syamsuddin, Tindak Pidana Khusus, 12.
} 
tahun manakala terjadi pengulangan tindak pidana (recidive) atau perbarengan tidak pidana (concursus) karena pidana yang dijatuhkan dapat ditambah sepertiganya atau ketika sebagai alternatif dari pidana mati pada tindak pidana tertentu. Keempat, pidana mati bukan sebagai pidana pokok yang diancamkan terhadap tindak pidana korupsi yang berdiri sendiri melainkan sebagai pidana pokok khusus yang diancamkan terhadap tindak pidana korupsi yang disertai alasan pemberatan pidana. ${ }^{37}$

\section{Kelebihan dan Kelemahan Pidana Denda}

Pidana denda yang ditentukan dalam undang-undang atau pidana denda yang dijatuhkan oleh hakim di pengadilan, selama ini belum mendapatkan perhatian bagi para ahli hukum pidana. Jenis pidana ini memang tidak semenarik pidana hilang kemerdekaan, seperti pidana penjara atau pidana seumur hidup, yang dianggap mempunyai efek jera yang paling efektif. Walaupun di balik itu banyak permasalahan dan pertanyaan yang timbul akibat sistem pemasyarakatan dalam penjara (lembaga pemasyaratan). Orang belum menghitung dan penegak hukum belum banyak mempertimbangkan bagaimana efisien dan efektifnya pidana denda jika diterapkan secara adil dan layak kepada terdakwa. ${ }^{38}$

Kata efektivitas, menurut Ensiklopedia Indonesia, menunjukkan taraf tercapainya suatu tujuan. Suatu usaha dikatakan efektif apabila usaha itu mencapai tujuannya. Adapun arti kata efektif berasal dari bahasa Inggris yakni effective yaitu baik hasilnya, mempan, tepat, benar. Sedangkan arti efektif menurut Kamus Besar Bahasa Indonesia yang dikeluarkan oleh Departemen Pendidikan dan Kebudayaan, berarti: ada efeknya (akibatnya, pengaruhnya, kesannya, manjur atau mujarap, dapat membawa hasil atau berhasil guna, mulai berlaku). Jadi efektivitas pemidanaan diartikan sebagai tingkat tercapainya tujuan yang ingin dicapai dengan adanya pemidanaan. suatu pemidanaan dikatakan efektif apabila tujuan yang ingin dicapai dengan adanya pemidanaan itu tercapai. ${ }^{39}$

Sudarto berpendapat bahwa pidana denda masih termasuk dalam paket sanksi. Pidana ini juga dipandang sebagai alternatif dari pidana

\footnotetext{
${ }^{37}$ Asmawi, Teori Maslahat dan Relevansinya dengan Perundang-undangan Pidana Khusus di Indonesia, 176.

${ }^{38}$ Suhariono Ar, Pembaharuan Pidana Denda Di Indonesia, 13.

${ }^{39}$ Niniek Suparni, Eksistensi Pidana Denda Dalam Sistem Pemidanaan, 59.
} 
pencabutan kemerdekaan. Di Eropa barat, pidana ini bahkan menjadi lebih penting daripada pencabutan kemerdekaan dan dipandang sebagai tidak kalah efektifnya, khususnya bagi orang-orang tertentu menurut keadaanya. ${ }^{40}$

Pidana denda merupakan jenis pidana pokok yang paling jarang dijatuhkan oleh para Hakim, khususnya dalam praktek peradilan di Indonesia. Faktor yang menyebabkankannya adalah jumlah ancaman pidana denda pada umumnya relatif ringan.

Menurut ketentuan yang terdapat dalam pasal $30 \mathrm{KUHP}$, tidak ada ketentuan batas waktu yang pasti kapan pidana denda itu harus dibayar. ${ }^{41}$ Di samping itu, tidak ada pula ketentuan mengenai tindakantindakan lain yang dapat menjamin agar terpidana dapat dipaksa untuk membayar dendanya, misalnya dengan jalan merampas atau menyita harta benda atau kekayaan terpidana.

Menurut sistem KUHP, alternatif yang dimungkinkan dalam hal terpidana tidak mau membayar denda tersebut, hanyalah dengan mengenakan kurungan pengganti. Padahal kurungan pengganti yang dimaksud dalam pasal 30 KUHP hanya berkisar antara 6 (enam) bulan atau dapat menjadi paling lama 8 (delapan) bulan. ${ }^{42}$

Dengan demikian maka betapapun tingginya pidana denda yang dijatuhkan hakim, akan tetapi apabila terpidana tidak mau membayar, konsekuensinya hanya 6 (enam) bulan atau dapat menjadi paling lama 8 (delapan) bulan seperti telah disebut diatas.

Seperti kejahatan korupsi, dalam hal yang bersangkutan melakukan tindak pidana yang dapat menghasilkan keuntungan materil yang jumlahnya sampai berjuta-juta rupiah atau bahkan bermilyaran rupiah tetap dapat menikmati hasil kejahatannya dengan tidak perlu khawatir harta benda atau kekayaannya, khususnya yang merupakan hasil kejahatan yang telah dilakukannya akan dirampas atau disita.

Meskipun Hakim dapat pula menjatuhkan sanksi tambahan berupa pidana perampasan barang-barang tertentu, namun pidana tambahan ini menurut sistem KUHP hanya bersifat fakultatif saja dan hanya dalam hal-hal tertentu saja yang bersifat imperatif. Lagi pula yang

\footnotetext{
${ }^{40}$ Sudarto, Pemidanaan Pidana dan Tindakan (Jakarta: Binacipta, 1980), 102.

${ }^{41}$ Niniek Suparni, Eksistensi Pidana Denda Dalam Sistem Pemidanaan, 66.

${ }^{42} \mathrm{lbid}, 67$.
} 
dirampas hanyalah barang-barang yang diduga diperoleh dari hasil kejahatan atau sengaja dipergunakan untuk melakukan kejahatan. ${ }^{43}$

Maka jelaslah bahwa dengan belum adanya perubahan kebijakan legislatif mengenai pelaksanaan pidana denda seperti yang terdapat dalam aturan hukum KUHP, maka tidak akan banyak artinya kebijakan untuk menaikkan jumlah ancaman pidana denda di luar KUHP.

Selain kedudukan pidana denda yang demikian itu di dalam sistem KUHP dan di luar KUHP yang sekarang berlaku, terdapat kelemahan pidana denda yang secara inherent terkandung di dalam pidana denda itu sendiri.

Adapun kelemahan-kelemahan tersebut adalah:

a. Bahwa pidana denda ini dapat dibayarkan atau ditanggung jawab oleh pihak ketiga (majikan, suami atau istri, orang tua, teman/kenalan baik, dan lainnya), sehingga pidana yang dijatuhkan tidak secara langsung dirasakan oleh si terpidana sendiri, hal mana membawa akibat tidak tercapainya sifat dan tujuan pemidanaan untuk membina si pembuat tindak pidana agar menjadi anggota masyarakat yang berguna, serta mendidik si pembuat tindak pidana untuk mempertanggungjawabkan perbuatannya. Tidaklah dengan demikian si pembuat tindak pidana akan berulang-kali berbuat tindak pidana lagi (karena misalnya memiliki bakat atau tingkah laku sebagai pembuat tindak pidana), sebab ia merasa bahwa pertanggung jawab akan dipikul oleh orang lain. Kalau pembayaran denda tidak dapat dipenuhi karena tidak mempunyai uang untuk membayar denda atau tidak ada barang yang dapat dilelang, bukankah tindak pidana lain yang baru lagi akan lahir untuk mendapatkan uang pembayar denda. Ini berarti tindak pidana yang satu melahirkan tindak pidana yang baru, dan keadaan ini dapat berlanjut seterusnya.

b. Bahwa pidana denda juga dapat membebani pihak ketiga yang tidak bersalah, dalam arti pihak ketiga dipaksa turut merasakan pidana tersebut, misalnya uang yang dilokasikan bagi pembayaran pidana denda yang dijatuhkan pada kepala rumah tangga yang melakukan kesalahan mengemudi karena mabuk, akan mencuitkan anggaran rumah tangga yang bersangkutan.

${ }^{43}$ lbid. 
c. Bahwa pidana denda ini lebih menguntungkan bagi orang-orang yang mampu, karena bagi mereka yang tidak mampu maka besarnya pidana denda tetap merupakan beban atau masalah, sehingga mereka cenderung untuk menerima jenis pidana yang lain yaitu pidana perampasan kemerdekaan.

d. Bahwa terdapat kesulitan dalam pelaksanaan penagihan uang denda oleh Jaksa selaku eskuator, terutama bagi terpidana yang tidak ditahan atau tidak berada dalam penjara. Di satu pihak dapat diadakan upaya paksa dalam bentuk peraturan perundang-undangan agar terpidana membayar denda dengan memberikan wewenang kepada Jaksa selaku eksekutor untuk melelang barang yang disita, dan kalau barang yang disita tidak ada yang baru diterapkan pidana pengganti denda. Akan tetapi di lain pihak, dengan melihat kondisi di Indonesia di mana masyarakat atau rakyatnya mayoritas masih hidup di dalam taraf di bawah sejahterah materil atau berkemampuan finansial, mungkinkah dapat memenuhi denda yang harus dibayar. ${ }^{44}$

Selain kelemahan-kelemahan pidana denda, di sisi lain pidana denda juga mempunyai kelebihan-kelebihan, yaitu:

1) Dengan penjatuhan pidana denda maka anomitas terpidana akan tetap terjaga, setiap terpidana merasakan kebutuhan untuk menyembunyikan identitas mereka atau anonim atau tidak kenal. Kebanyakan dari mereka takut dikenali sebagai orang yang perna mendekam dalam penjara oleh lingkungan sosial atau lingkungan kenalan mereka.

2) Pidana denda tidak menimbulkan stigma atau cap jahat bagi terpidana, sebagaimana halnya yang dapat ditimbulkan dari penerapan pidana perampasan kemerdekaan.

3) Dengan penjatuhan pidana denda, negara akan mendapatkan pemasukan dan di samping proses pelaksanaan hukumnya lebih mudah dan murah. ${ }^{45}$

\section{Tujuan Pidana Denda}

Tujuan dijatuhkannya pidana adalah agar para pelaku jera dan tidak mau mengulangi perbuatannya lagi. Selain itu, sanksi dalam

${ }^{44} \mathrm{lbid}$.

${ }^{45} \mathrm{lbid}$. 
hukum pidana dimaksudkan sebagai penguat agar norma-norma yang telah ditetapkan dapat ditaati, sehingga tercipta ketertiban dan kedamaian di masyarakat. Masyarakat menganggap bahwa pidana itu menjadi pelindung dari ancaman pidana.

Menurut Sudarto, pidana adalah nestapa yang diberikan oleh negara kepada seseorang yang melakukan pelanggaran terhadap ketentuan Undang-undang, sengaja agar dirasakan sebagai nestapa. ${ }^{46}$ Pemberian nestapa atau penderitaan yang sengaja dikenakan kepada seorang pelanggar ketentuan Undang-undang tidak lain dimaksudkan agar orang itu menjadi jera. Hukum pidana sengaja mengenakan penderitaan dalam mempertahankan norma-norma yang diakui dalam hukum. Sanksi yang tajam dalam hukum pidana inilah yang membedakan dengan bidang-bidang hukum yang lain. Inilah sebabnya mengapa hukum pidana harus dianggap sebagai sarana terakhir apabila sanksi atau upaya-upaya pada bidang hukum yang lain tidak memadai.

Roeslan Saleh menyatakan bahwa pidana adalah reaksi-reaksi atas delik, yang berwujud suatu nestapa yang sengaja ditampakkan negara kepada pembuat delik. ${ }^{47}$

Pada dasarnya pengertian pidana menurut Roeslan Saleh ini hampir sama dengan pengertian pidana menurut Sudarto, yaitu bahwa pidana berwujud suatu nestapa yang diberikan negara kepada pelanggar. Reaksi-reaksi atas delik yang telah dikemukakan oleh Roeslan Saleh menunjukkan bahwa suatu delik dapat memberikan reaksinya atau imbalannya apabila dilanggar, yaitu berupa ancaman hukuman atau pidana.

Akan tetapi tidak semua menyetujui pendapat bahwa hakikat pidana adalah pemberian nestapa, hal ini antara lain diungkapkan oleh Hulsman sebagaimana dikutip oleh Mulyadi, bahwa pidana adalah menyerukan untuk tertib, pidana pada hakikatnya mempunyai dua tujuan utama yakni untuk mempengarui tingka laku dan untuk menyelesaikan konflik..$^{48}$

Pidana di satu sisi tidak hanya dimaksudkan untuk memberikan penderitaan kepada pelanggar atau membuat jera, tapi di sisi yang lain

\footnotetext{
${ }^{46}$ Sudarto, Kapita Selekta Hukum Pidana, 109.

${ }^{47}$ Roeslan Saleh, Stesel Pidana Indonesia (Jakarta: Bina Aksara, 1987), 5.

${ }^{48}$ Sudarto, Kapita Selekta Hukum Pidana, 11.
} 
juga agar membuat pelanggar dapat kembali hidup bermasyarakat sebagaimana layaknya.

Tujuan penjatuhan pidana di atas berlaku pula bagi pidana denda yang dikenakan secara rasional dan proposional, baik terhadap orangperseorangan maupun korporasi.

Pidana denda sebagai alternatif atau pengganti pidana penjara, dapat diartikan sebagai penukar derita atau nestapa terhadap pidana penjara menjadi derita atau nestapa dengan mengurangi hak kepemilikan benda atau harta pelaku tindak pidana sebagai hukuman. pengalihan dari pidana penjara ke pidana denda merupakan pemidanaan yang lebih bersifat humanis atau dapat diartikan lebih manusiawi atau berprikemanusiaan sebagai perwujudan pelaksanaan sila kedua pancasila.

Kemanusiaan yang adil dan beradab sebagai sila kedua dalam Pancasila mengandung pengertian adanya kesadaran sikap dan perbuatan manusia yang didasarkan kepada potensi budi nurani manusia dalam hubungannya dengan norma-norma dan kebudayaan umumnya, baik pada diri pribadi, sesama manusia, maupun pada alam sekitarnya atau lingkungan hidup. Potensi kemanusian dimiliki oleh semua manusia di dunia, tanpa memandang ras, keturunan dan warna kulit serta bersifat Universal. ${ }^{49}$ Dalam sila kemanusiaan, terkandung nilai-nilai bahwa negara harus menjunjung tinggi harkat dan martabat manusia sebagai makhluk yang beradap. Oleh karena itu, dalam kehidupan kenegaraan terutama dalam peraturan perundang-undangan negara harus mewujudkan tercapainya tujuan ketinggian harkat dan martabat manusia, terutama hak-hak kodrat manusia sebagai hak dasar (hak asasi) harus dijamin peraturan perundang-undangan negara. Nilai kemanusiaan yang beradap adalah perwujudan nilai kemanusiaan sebagai makhluk yang berbudaya, bermoral dan beragama. ${ }^{50}$

\section{Korupsi di Tingkat Extraordinary Crime}

Seperti yang diketahui korupsi menimbulkan dampak yang luar biasa bagi sendi kehidupan bernegara dan mengingat perkembangannya sebagai tindak pidana berat yang sering dikategorikan menjadi kejahatan

\footnotetext{
49 Subandi Al Marsudi, Pancasila dan UUD 1945 dalam Paradigma Reformasi (Jakarta: PT Raja Grafindo Persada, 2004), 53.

${ }^{50} \mathrm{lbid}$.
} 
yang luar biasa (extraordinary crime), ${ }^{51}$ yang memerlukan cara-cara luar biasa juga untuk menanggulanginya (extraordinary measures), dan seringkali cara-cara luar biasa ini harus menyimpang dari asas-asas hukum pidana umum, baik hukum pidana materiil (KUHP) maupun hukum acara pidana (KUHAP).

Selain itu, upaya pencegahan dan pemberantasan kejahatan korupsi perlu dilakukan secara terus menerus dan berkesinambungan serta perlu didukung oleh berbagai sumber daya, baik sumber daya manusia maupun sumber daya lainnya seperti peningkatan kapasitas kelembagaan serta peningkatan penegakan hukum guna menumbuhkan kesadaran dan sikap tindak masyarakat yang anti korupsi.

Pada tahun 2002, pemerintah menerbitkan Undang-undang Nomor 30 Tahun 2002 tentang Komisi Pemberantasan Korupsi yang dikenal dengan KPK. KPK kerap dijuluki oleh kalangan hukum sebagai lembaga superbody karena wewenang yang dimilikinya luar biasa besar untuk menyelidiki, menyidik, dan menuntut setiap orang, pegawai negeri, penyelenggara negara, dan bahkan korporasi yang diduga telah melakukan korupsi, sehingga menimbulkan kerugian pada keuangan atau perekonomian negara. ${ }^{52}$

Meskipun ada lagi penyidik dari Polri dan penyidik dari Kejaksaan Agung yang memang memiliki wewenang penyidikan. Disinilah terjadi tumpang tindih wewenang manakala penyidik-penyidik dari institusi yang berbeda tersebut menangani satu kasus kejahatan korupsi yang sama. Wewenang yang dimiliki oleh tiga lembaga ini yaitu, Polri berdasarkan Undang-undang Nomor 2 Tahun 2002 tentang Kepolisian Negara Republik Indonesia, dalam pasal 14 huruf g ditegaskan "Kepolisian Negara Republik Indonesia bertugas melakukan penyelidikan dan penyidikan terhadap semua tindak pidana sesuai dengan hukum acara pidana dan peraturan perundang-undangan lainnya". ${ }^{53}$

Kejaksaan dalam Undang-Undang Nomor 16 Tahun 2004 tentang Kejaksaan Republik Indonesia Pasal 30 menjelaskan: ${ }^{54}$

1. Di bidang pidana, kejaksaan mempunyai tugas dan wewenang:

\footnotetext{
${ }^{51}$ Aziz Syamsuddin, Tindak Pidana Khusus, 7.

52 Ibid, 193.

${ }^{53}$ Evi Hartati, Tindak Pidana Korupsi, 41.

${ }^{54} \mathrm{lbid}, 34$.
} 

a. melakukan penuntutan;
b. melaksanakan penetapan hakim dan putusan pengadilan yang telah memperoleh kekuatan hukum tetap;
c. melakukan pengawasan terhadap pelaksanaan putusan pidana bersyarat, putusan pidana pengawasan, dan keputusan lepas bersyarat;
d. melakukan penyidikan terhadap tindak pidana tertentu berdasarkan undang-undang;
e. melengkapi berkas perkara tertentu dan untuk itu dapat melakukan pemeriksaan tambahan sebelum dilimpahkan ke pengadilan yang dalam pelaksanaannya dikoordinasikan dengan penyidik.

2. Di bidang perdata dan tata usaha negara, kejaksaan dengan kuasa khusus dapat bertindak baik di dalam maupun di luar pengadilan untuk dan atas nama negara atau pemerintah.

Pada pasal 11 Undang-Undang Nomor 30 Tahun 2002 KPK diberi wewenang dalam melakukan penyelidikan, penyidikan, dan penuntutan kejahatan korupsi yang:

1) Melibatkan aparat penegak hukum, penyelenggara negara, dan orang lain yang ada kaitannya dengan tindak pidana korupsi yang dilakukan oleh aparat penegak hukum atau penyelenggara negara,

2) Mendapat perhatian yang meresahkan masyarakat, dan/atau

3) Menyangkut kerugian negara paling sedikit Rp1.000.000.000,00 (satu miliar rupiah).

Kelebihan lain KPK dibandingkan Kepolisian dan Kejaksaan adalah KPK tidak berwenang mengeluarkan Surat Perintah Penghentian Penyidikan dan Penuntutan dalam perkara korupsi, sebagaimana wewenag yang dimiliki Kepolisian dan Kejaksaan. Hal ini untuk menghindari adanya 'main mata' antara tersangka dan aparat KPK. ${ }^{55}$

Sepatutnya setiap institusi penegak hukum mulai dari Kepolisian Kejaksaan serta KPK memiliki pemahaman dan persepsi yang sama tentang sistem penegakan hukum atas perkara-perkara kejahatan korupsi. Tidak kalah pentingnya pula, setiap lembaga tersebut menjalankan peranan sesuai dengan batasan wewenangnya masing-masing, sehingga pada akhirnya akan terbangun kesamaan persepsi, menguatnya

\footnotetext{
${ }^{55}$ Lihat Undang-Undang Nomor 30 Tahun 2002 tentang Komisi Pemberantasan Korupsi Pasal 40
} 
kesinambungan tugas, serta bersinerginya semangat dengan tindakan di antara aparatur atau institusi penegak hukum.

Penanganan kejahatan korupsi di Indonesia yang tumpang tindih harus segera diakhiri dengan mengambil kebijakan nasional saat ini adalah menerapkan integrated legal system kepada seluruh institusi penegak hukum. Dan ke depan perkara-perkara kejahatan korupsi seyogyanya hanya ditangani satu lembaga yang memiliki wewenang khusus untuk itu, yaitu KPK (penyelidikan, penyidikan, dan penuntutan) dan tidak lagi melibatkan institusi penegak hukum lain. Kepolisian dan Kejaksaan dapat berkonsentrasi pada kejahatan-kejahatan pidana lain yang berkualitas dan kuantitasnya tidak kalah seriusnya. ${ }^{56}$

\section{Analisis Ketentuan Pidana Denda dalam Kejahatan Korupsi Tingkat Extraordinary Crime Menurut Hukum Pidana Islam}

Ditinjau dari segi pemidanaan, pidana denda dalam korupsi dengan hukum pidana Islam mempunyai persamaan yaitu hukuman bagi orang yang berdosa dengan cara membayar harta sebagai sanksi atas dosanya. ${ }^{57}$

Hukuman atau jarîmah dalam Islam terdiri dari atas had, qisas dan $t^{\prime} z i r^{58}{ }^{58}$ Sedangkan sanksi bagi pelaku ghulûl adalah ta'zîr karena harta yang dicuri merupakan harta yang syubhat (harta negara/baitul mal) dan merupakan harta milik umum, sama halnya anak mencuri harta bapaknya, istri mencuri harta suaminya maka tidak dikenakan had tetapi ta'zîr. Hukuman ta'zîr ini jenisnya beragam salah satunya hukuman ta'zîr berkaitan dengan harta.

Ditinjau dari status hukumnya, para ulama berbendapat tentang dibolehkannya hukuman ta'zîr dengan cara mengambil harta. Menurut Imam Abu Hanifah, hukuman ta'zîr degan cara mengambil harta tidak dibolehkan. Pendapat ini diikuti oleh muridnya, yaitu Muhammad Ibn Hasan, tetapi muridnya yang lain, yaitu Imam Abu Yusuf membolehkannya apabila dipandang membawa maslahat. Pendapat ini

\footnotetext{
${ }^{56}$ Aziz Syamsuddin, Tindak Pidana Khusus, 193.

${ }^{57}$ Abdurrahman Al-Maliky, Sistem Sanksi Dalam Islam, 269.

58 Ahmad Wardi Muslich, Pengantar Dan Asas Hukum Pidana Islam-Fikih Jinayah (Jakarta: Sinar Grafika, 2006), 22.
} 
diikuti oleh Imam Malik, Imam Syafi'i, dan Imam Ahmad Ibn Hambal. ${ }^{59}$

Ditinjau dari pengertiannya, para ulama yang membolehkan hukuman ta'zîr dengan cara mengambil harta, terutama dari Hanafiyah dengan redaksi:

"Hakim menahan sebagian harta si terhukum selama waktu tertentu, sebagai pelajaran dan upaya pencegahan atas perbuatan yang dilakukannya, kemudian mengembalikannya kepada pemiliknya apabila ia telah jelas taubatnya" 60

Hal tersebut mengandung pengertian bahwa salah satu bentuk sanksi ta'zîr menganut pendekatan restorative justice dengan berpangkal tolak pada upaya pencegahan, rekonsiliasi dan pemaafan dalam rangka perdamaian. $^{61}$

Ditinjau dari macam-macamnya, Imam Ibn Taimiyah membagi hukuman ta'zîr berupa harta ini kepada tiga bagian, dengan memperhatikan atsar (pengaruhnya) terhadap harta yaitu, menghancurkannya, mengubahnya atau memilikinya.

Penghancuran barang ini tidak selamnya merupakan kewajiban, melainkan dalam kondisi tertentu boleh dibiarkan atau disedekahkan. Atas dasar pemikiran ini, maka sekelompok ulama seperti Imam Malik dalam riwayat Ibn Al-Qasim, dengan menggunakan istihs $n$ membolehkan itl $f$ (penghancuran) atas makanan yang dijual melalui penipuan dengan cara disedekahkan kepada fakir miskin, seperti Khalifah Umar perna menumpahkan susu yang bercampur dengan air untuk dijual. Dengan demikian dua kepentingan yaitu it $f$ (penghancuran) sebagai hukuman dan manfaat bagi orang miskin, sekaligus dapat dicapai. ${ }^{62}$ Adapun hukuman ta'zîr berupa mengubah harta pelaku antara lain seperti mengubah patung yang disembah oleh orang muslim dengan cara memotong bagian kepalanya, sehingga mirip dengan pohon. Hukuman ta'zîr berupa pemilikan harta penjahat (pelaku), antara lain seperti keputusan Rasulullah saw, melipat gandakan denda bagi seorang yang mencuri buah-buahan, disamping hukuman dera.

\footnotetext{
${ }^{59}$ Ahmad Wardi Muslich, Hukum Pidana Islam, 265.

${ }^{60} \mathrm{lbid} ., 266$.

${ }^{61}$ Marwan Effendy, Sistem Peradilan Pidana (Jakarta: Referensi, 2012), 113.

${ }^{62}$ Ahmad Wardi Muslich, Hukum Pidana Islam, 266.
} 
Seperti uraian yang telah dikemukakan di atas, khususnya pada bagian ketiga dari jenis ta'zîr dengan harta, dapat diketahui bahwa wujud dari pemilikan harta itu adalah denda atau dalam bahasa Arab disebut ghar mah. Maka hukuman denda sebagai salah satu jenis hukuman ta'zîr dalam syariat Islam. ${ }^{63}$

Syariat Islam tidak menetapkan batas terendah atau tertinggi dari hukuman denda. Hal ini sepenuhnya diserahkan kepada hakim dengan mempertimbangkan berat ringanya jarîmah yang dilakukan oleh pelaku. Secara terminologis, ta'zîr adalah bentuk hukuman yang tidak disebutkan ketentuan kadar hukumnya oleh syara' dan menjadi kekuasaan waliyyul amri atau hakim. ${ }^{64}$

Selain denda, hukuman ta'zîr yang berupa harta adalah penyitaan atau perampasan harta. Namun hukuman ini diperselisihkan oleh para fuqaha. Jumhur ulama membolehkannya apabila persyaratan untuk mendapat jaminan atas harta tidak dipenuhi. Syarat-syarat tersebut adalah sebagai berikut: ${ }^{65}$

1. Harta diperoleh dengan cara yang halal.

2. Harta itu digunakan sesuai dengan fungsinya.

3. Penggunaan harta itu tidak mengganggu hak orang lain.

Apabila persyaratan tersebut tidak dipenuhi, misalnya harta didapat dengan jalan yang tidak halal, atau tidak digunakan sesuai dengan fungsinya maka dalam keadaan seperti itu, Ulil Amri berhak untuk menerapkan hukuman ta'zîr berupa penyitaan atau perampasan sebagai sanksi terhadap perbuatan yang dilakukan oleh pelaku seperti kejahatan korupsi. ${ }^{66}$

\section{Analisis Kejahatan Korupsi di Tingkat Extraordinary Crime Menurut Hukum Pidana Islam}

Indonesia adalah negara yang berdasarkan hukum, adapun negara yang berdasarkan hukum maka akan memiliki prinsip supremancy before the law, yakni hukum diberi kedudukan yang tertinggi. Hukum berkuasa penuh atas negara dan rakyat, dan juga equality before the law yakni

\footnotetext{
${ }^{63}$ Abdurrahman Al-Maliky, Sistem Sanksi Dalam Islam, 246.

${ }^{64}$ Rahmat Hakim, Hukum Pidana Islam (Fiqih Jinayah) (Bandung: CV. Pustaka Sena, 2000), 140141.

${ }^{65}$ Ahmad Wardi Muslich, Hukum Pidana Islam, 267.

${ }^{66}$ Ibid., 267.
} 
semua memiliki status yang sama di hadapan hukum. ${ }^{67}$ Maka siapapun orangnya dan setinggi apapun jabatannya tetap akan mendapatkan hak dan perlakuan yang sama di hadapan hukum.

Kejahatan korupsi dapat dilakukan oleh siapapun, baik dari kalangan pejabat, penegak hukum, pegawai atau dari kalangan rendah. Karena hukuman berlaku bagi siapapun yang bersalah. Maka dalam hukum pidana, orang yang melakukan tindak pidana korupsi dijerat dengan Undang-Undang Nomor 20 Tahun 2001 tentang Tindak Pidana Korupsi pada pasal 2 ayat (1):

"Setiap orang yang secar melawan hukum melakukan perbuatan memperkaya diri sendiri atau orang lain atau suatu korporasi yang dapat merugikan keungan negara atau perekonomian negara dipidana dengan pidana penjara paling sedikit empat tahun dan paling lama 20(dua puluh) tahun dan denda paling sedikit $\mathrm{Rp}$ 200.000.000,00 (dua ratus juta rupiah) dan paling banyak $\mathrm{Rp}$ 1.000.000.000,00 (satu miliar rupiah). ${ }^{368}$

Selanjutnya, Menurut UU No. 31 Tahun 1999 jo. UU No. 20 Tahun 2001, bentuk sanksi pidana yang dapat dikenakan kepada pelaku tindak pidana korupsi adalah pidana penjara dan pidana denda. ${ }^{69}$ Namun hampir bisa dipastikan bahwa tiap-tiap putusan hakim selalu menempatkan pidana penjara sebagai garda terdepan dalam upaya mewujudkan tujuan pemidanaan. Padahal, pidana penjara sendiri mengandung kelemahan, seperti perampasan kemerdekaan seseorang, pemborosan keuangan negara, dan stigmatisasi yang akan selamanya melekat pada seseorang. ${ }^{70}$ Karena kelemahan-kelemahan itulah, usaha untuk meminimalisasi penggunaaan pidana penjara dan menjadikan pidana denda sebagai alternatif pidana semakin mengemuka. Pidana denda semakin banyak digunakan baik dalam perundang-undangan pidana di luar KUHP maupun dalam undang-undang administrasi.

Dalam peradilan tindak pidana korupsi, hakim sudah memiliki keberanian untuk mengenakan pidana denda dengan nilai yang tinggi bagi pelaku tindak pidana korupsi dan sudah sesuai dengan minimum pidana dengan yang diatur dalam undang-undang tindak pidana

${ }^{67}$ C.S.T Kansil, Hukum Antar Tata Pemerintahan (Jakarta: Erlangga, 1987), 26.

${ }^{68}$ Lihat UU No. 20 Tahun 2001 tentang Pemberantasan Tindak Pidana Korupsi Pasal 2 ayat 1

${ }^{69}$ Evi Hartati, Tindak Pidana Korupsi, 12.

${ }^{70}$ Aziz Syamsuddin, Tindak Pidana Khusus, 154. 
korupsi. ${ }^{71}$ Namun sebagian besar seluruh perkara korupsi terbukti sah dan meyakinkan, terutama dalam Pengadilan Tindak Pidana Korupsi yang ditangani oleh KPK cenderung sulit mengeksekusi pidana denda dan ganti kerugian dalam tindak pidana korupsi dan menjadi masalah yang belum dapat diselesaikan.

Penjatuhan pidana denda yang tinggi tidak akan efektif dalam pelaksanaannya mengingat adanya ketentuan bilamana denda tidak dibayar akan diganti dengan kurungan, sebagaimana termaktub dalam pasal 30 KUHP. Selain itu, ketentuan pasal 30 KUHP tidak mengatur batas waktu yang pasti kapan denda itu harus dibayar. Demikian juga tidak ada ketentuan mengenai tindakan-tindakan lain yang menjamin agar terpidana dapat dipaksa untuk membayar dendanya. ${ }^{72}$

Artinya, walaupun hakim menjatuhkan pidana denda tinggi, pelaku tindak pidana korupsi cenderung memilih hukuman kurungan selama enam (6) bulan atau delapan (8) bulan jika terdapat pemberatan denda daripada harus membayar denda yang dijatuhkan pengadilan kepadanya. Oleh karena itu, ketentuan tersebut seharusnya disimpangi dan diganti dengan membayar denda dari harta kekayaan pelaku maupun keluarganya, baik melalui cicilan maupun dengan cara lain.

Jalan keluarnya adalah menciptakan adanya ketentuan atau suatu peraturan yang bersifat memaksa sehingga terpidana mau tak mau harus membayar denda tersebut. Misalnya KPK diberi wewenang untuk melelang di muka umum barang yang sudah disita (bukan yang dirampas) kemudian memotong uang denda dari hasil lelang tersebut. Hal ini dapat dijalankan apabila terpidana sesudah diberikan waktu yang lama tapi tetap tidak mau membayar denda. Kalau barang yang akan disita sudah tidak ada lagi, barulah diterapkan pengganti denda. ${ }^{73}$

Dengan adanya pengaturan pidana denda yang tinggi dalam Undang-Undang Pemberantasan Tindak Pidana Korupsi, setidaknya memberikan sumbangan dalam mengurangi tindak pidana korupsi, walaupun Undang-undang tersebut mengatur juga tentang pidana tambahan tertuang dalam pasal 18 UU No. 31 Tahun 1999 jo. UU No. 21 Tahun 2001. Dengan belum adanya kebijakan legislatif mengenai

\footnotetext{
${ }^{71}$ Syaiful Bakhri, Pidana Denda dan Korupsi(Jakarta: Total Media), 319.

72 Ibid., 225.

${ }^{73}$ Ninik suparni, Eksistensi Pidana Denda dalam Sistem Pidana dan Pemidanaan, 58.
} 
pelaksanaan pidana denda sebagaimana yang diatur dalam aturan umum KUHP, maka tidak akan banyak artinya kebijakan untuk menaikkan jumlah ancaman pidana denda di luar KUHP tanpa adanya perubahan di dalam KUHP itu sendiri. ${ }^{74}$

RUU KUHP yang baru juga telah dirumuskan alternatif pengganti dari pidana denda yang tidak dapat dibayar adalah pidana pengawasan atau pelayanan masyarakat (social services). Misalnya, ketentuan pidana denda di jepang menunjukkan bahwa seseorang yang tidak mampu membayar dendanya, baik seluruh maupun sebagian. Dapat ditahan dalam tempat kerja paling kurang satu hari dan paling lama dua tahun dalam work house tanpa dibayar. Kemudian, pada umumnya di Eropa, seperti di Jerman, Belanda, dan Luxembrurg, dalam perundang-undangannya terhadap pidana denda yang tidak dibayar dapat diganti dengan bekerja tanpa bayaran. ${ }^{75}$ Dengan adanya alternatif tersebut, maka pembayaran denda lebih dipertegas kemungkinan eksekusinya. $^{76}$

RUU KUHP terdapat juga formulasi baru mengenai pidana denda, yaitu hakim dapat memilih atau menentukan sanksi pidana denda saja, walaupun dimungkinkan adanya sanksi penjara. Dengan adanya model kategorisasi dan pelaksanaann pidana denda dengan cicilan dan dapat dibayar oleh pihak lain yang diatur dalam RUU KUHP adalah bentuk rasional dalam pemidanaan yang sangat maju dan modern. Hampir di setiap ketentuan mengenai pidana denda terdapat alternatif ke dalam ketegori ringan, sedang, bahkan pengancaman dengan kategori tinggi. ${ }^{77}$

Hal lain yang perlu diperhatikan juga adalah penetapan pidana denda sebaliknya memperhatikan prinsip proporsionalitas. Makna proporsional adalah termasuk memandang bahwa pembalasan itu semata-mata atas kesalahan pelaku tindak pidana. Asas pembalasan harus mencerminkan bahwa pelaku tidak boleh dihukum dengan bobot yang tidak seimbang dengan kesalahannya, prinsip ini bermakna bahwa sanksi

\footnotetext{
74 Saiful Bakhri, "Kebijakan Legislatif Tentang Pidana Denda dan Penerapannya dalam Upaya Penanggulanagan Tindak Korupsi", www.law.Ull.co.id

${ }^{75}$ Suharino AR, Pembaruan Pidana Denda di Indonesia, 247.

${ }^{76}$ Ninik suparni, Eksistensi Pidana Denda dalam Sistem Pidana dan Pemidanaan, 61.

77 lbid., 62.
} 
yang dikenakan harus sesuai dengan beratnya pelanggaran yang telah dilakukan. ${ }^{78}$

\section{Simpulan}

Ketentuan pidana denda dalam kejahatan korupsi di tingkat extraordinary crime adalah hukuman berupa kewajiban bagi seseorang yang telah melanggar larangan dalam rangka mengembalikan keseimbangan hukum atau menebus kesalahan dengan pembayaran dengan sejumlah uang tertentu. Dari berbagai permasalahan dan dibahas pada bab-bab sebelumnya, maka dapat diambil kesimpulan sebagai berikut:

1. Ketentuan pidana denda dalam kejahatan korupsi di tingkat extraordinary crime sudah diatur dalam UU No. 20 Tahun 2001 tentang Pemberantasan Tindak Pidana Korupsi dalam pasal 2 ayat (1). Tetapi penerapannya belum terlalu efektif karena hakim lebih banyak memilih pidana penjara menjadi pidana pokok, padahal pidana denda mempunyai maanfaat lebih baik dari pada sanksi pidana perampasan dan memiliki efektivitas dalam membuat jera pelaku korupsi.

2. Ketentuan pidana denda dalam kejahatan korupsi di tingkat extraordinary crime ditinjau hukum pidana Islam mempunyai kesamaan yaitu hukuman bagi orang yang berdosa dengan cara membayar harta sebagai sanksi atas dosanya. Selain itu ada persamaan tentang korupsi sebagai kejahatan luar biasa dapat dikenai hukuman mati dengan persyaratan tertentu antara lain dampak yang ditimbulkan dan keadaanya sebagai pengulangan tindak pidana (residivis). Tentu ada pula perbedaannya antara pidana denda dalam kejahatan korupsi di tingkat extraordinary crime dengan hukum pidana Islam yaitu penerapan pidana denda dengan menggunakan prinsip proposional bahwa sanksi yang dikenakan harus sesuai dengan beratnya pelanggaran yang telah dilakukan. Sedangkan hukum pidana Islam menggunakan prinsip restorative justice dengan berpangkal tolak pada upaya pencegahan, rekonsiliasi dan pemaafan dalam rangka perdamaian. Kemudian hukum denda dalam pidana Islam

\footnotetext{
${ }^{78}$ Saiful Bakhri, "Kebijakan Legislatif Tentang Pidana Denda dan Penerapannya dalam Upaya Penanggulanagan Tindak Korupsi", www.law.Ull.co.id
} 
tidak menetapkan batas terendah atau tertinggi, hal sepenuhnya diserahkan kepada hakim.

\section{Daftar Rujukan}

Al Marsudi, Subandi. Pancasila dan UUD 1945 dalam Paradigma Reformasi. Jakarta: PT Raja Grafindo Persada, 2004.

Al-Maliky, Abdurrahman. Sistem Sanksi dalam Islam. terj. Syamsuddin Ramadhan. judul asli: Nizam al-Uqubat. Bogor: Pustaka Thariqul Izzah. Cet. 1, 2002.

AR, Suhariono. Pembaharuan Pidana Denda di Indonesia. Jakarta: Papas Sinar Sinanti, 2012.

Asmawi. Teori Maslahat dan Relevansinya dengan Perundang-undangan Pidana Khusus di Indonesia. Jakarta: Badan LITBANG dan DIKLAT, t.th.

Bakhri, Saiful. Kebijakan Legislatif tentang Pidana Denda dan Penerapannya dalam Upaya Penanggulanagan Tindak Korupsi. dalam www.law.UII.co.id

--------. Pidana Denda dan Korupsi. Jakarta: Total Media, t.th.

D, Soedjono. Sistem Peradilan Pidana Peraturan Umum dan DelikDelik Khusus. Jakarta: Rajawali Pers, 1989.

Departemen Agama RI. Al-Qur'an dan Terjemahannya. Surabaya: Pustaka Agung Harapan, 2006.

Djaja, Ermannsjah. Meredesain Pengadilan Tindak Pidana Korupsi Implikasai Putusan Mahkamah Konstitusi Nomor 012-016019/PPUIV/2006. Jakarta: Sinar Grafika, 2010.

--_-----. Memberantas Korupsi Bersama KPK. Jakarta: Sinar Grafika, 2008.

Effendy, Marwan. Sistem Peradilan Pidana. Jakarta: Referensi, 2012.

Fu'ady, Munir. Perbuatan Melawan Hukum. Bandung: PT. Citra Aditya Bhakti, 2005.

Hakim, Rahmat. Hukum Pidana Islam (Fiqih Jinâyah). Bandung: CV. Pustaka Sena, 2000.

Hamdan, M. Politik Hukum Pidana. Jakarta: PT Raja Grafindo Persada, 1997. 
Hamzah, Andi. Pemberantasan Korupsi Melalui Hukum Pidana Nasional dan Internasional. Jakarta: Rajagrafindo Persada, 2007.

Hartati, Evi. Tindak Pidana Korupsi. Jakarta: Sinar Grafika, 2007.

Kansil, C.S.T. Hukum Antar Tata Pemerintahan. Jakarta: Erlangga, 1987.

Moeljatno. KUHP. Jakarta: PT Bumi Aksara, 2008.

Muladi, dan Barda Nawawi A. Teori-teori dan Kebijakan Pidana. Bandung: Alumni, 1992.

Muslich, Ahmad Wardi. Hukum Pidana Islam. Jakarta: Sinar Grafika, 2005.

--------. Pengantar dan Asas Hukum Pidana Islam-Fikih Jinâyah. Jakarta: Sinar Grafika, 2006.

Poerwadarminta, W.J.S. Kamus Umum Bahasa Indonesia. Jakarta: Balai Pustaka, 1976.

Saleh, Roeslan. Stesel Pidana Indonesia, Jakarta: Bina Aksara, 1987.

Sudarto. Pemidanaan Pidana dan Tindakan. Jakarta: Binacipta, 1980.

Suparni, Niniek. Eksistensi Pidana Denda dalam Sistem Pidana dan Pemidanaan. Jakarta: Sinar Grafika, 1996.

Syamsuddin, Aziz. Tindak Pidana Khusus. Jakarta: Sinar Grafika, 2011.

Waluyo, Bambang. Pidana dan Pemidanaan, Jakarta: Sinar Grafika, 2000.

Undang-Undang Nomor 30 Tahun 2002 tentang Komisi Pemberantasan Korupsi Pasal 40

UU No. 20 Tahun 2001 tentang Pemberantasan Tindak Pidana Korupsi Pasal 2 ayat 1

UU No. 3 Tahun 1971 tentang Pemberantasan Tindak Pidana Korupsi

UU No. 46 Tahun 2009 tentang Pengadilan Tindak Pidana Korupsi 